\title{
OSMIUM(II) AND RUTHENIUM(II) COMPLEXES OF TRICYCLOHEXYLPHOSPHINE ${ }^{1}$
}

\author{
BY \\ F. G. MOERS and J. P. LANGHOUT \\ (Inorganic Chemistry Laboratory, University of Nijmegen, Toernooiveld, Nijmegen, \\ The Netherlands)

\begin{abstract}
The preparation of tricyclohexylphosphine complexes of osmium and ruthenium is reported. The reaction of $\mathrm{K}_{2} \mathrm{OsCl}_{6}$ or hydrated $\mathrm{RuCl}_{3}$ with tricyclohexylphosphine $\left(\mathrm{PCy}_{3}\right)$ in 2-methoxyethanol leads to the complexes $\mathrm{MHCl}(\mathrm{CO})\left(\mathrm{PCy}_{3}\right)_{2}$ with $\mathbf{M}=\mathrm{Os}$ or $\mathrm{Ru}$. Hydrogen-deuterium exchange of $\mathrm{PCy}_{3}$ was observed in these complexes on reaction with deuterium gas and in the complexes prepared with deuteriated ethanol. Addition of pyridine (py) gives complexes of the formula $\mathrm{MHCl}(\mathrm{CO})\left(\mathrm{PCy}_{3}\right)_{2}$ (py). Phosphonium compounds containing iron(III) and osmium(IV) halides as anions were prepared and characterised.
\end{abstract}

\section{Introduction}

In a previous communication ${ }^{2}$ we reported the isolation of the complex OsHCl(CO) $\left(\mathrm{PCy}_{3}\right)_{2}$. This hydridocarbonyl complex is a new type of compound and shows an appreciable deuteriation of $\mathrm{PCy}_{3}$ during the preparation of the deuteriated derivative with deuteriated ethanol. We now report the preparation and physical properties of osmium, ruthenium and iron complexes with tricyclohexylphosphine. In addition the results of the interaction of the hydridocarbonyl complexes with deuterium are presented.

\section{Results and discussion}

The new complexes are listed in Table I, along with their analytical results, colours and magnetic moments.

\section{(a) Hydridocarbonyl complexes}

The complexes were obtained directly from the metal halides, phosphine and 2-methoxyethanol. This is the common method of preparing

1 Presented in part at the Symposium "on the reactivity of coordinated ligands" by F. G. M., Leeds, April 1971.

2 F. G. Moers, Chem. Comm. 2, 79 (1971). 
Table I

Analysis data and properties of the complexes.

\begin{tabular}{|c|c|c|c|c|c|c|c|}
\hline Complex & Colour & $\begin{array}{l}\mathrm{C} \\
(\%)\end{array}$ & $\begin{array}{l}\mathrm{H} \\
(\%)\end{array}$ & $\begin{array}{c}X \\
(\%)\end{array}$ & $\begin{array}{l}N \\
(\%)\end{array}$ & $\begin{array}{c}0 \\
(\%)\end{array}$ & $\begin{array}{l}\text { Magnetism } \\
\text { (B.M) }\end{array}$ \\
\hline $\mathrm{OsHCl}(\mathrm{CO})\left(\mathrm{PCy}_{3}\right)_{2}$ & $\begin{array}{l}\text { Crystals red } \\
\text { Powder yellow }\end{array}$ & $\begin{array}{c}54.36 \\
(54.49)\end{array}$ & $\begin{array}{c}8.36 \\
(8.28)\end{array}$ & $\begin{array}{c}4.56 \\
(4.35)\end{array}$ & & $\begin{array}{c}2.13 \\
(1.96)\end{array}$ & Diamagnetic \\
\hline $\mathrm{OsHCl}(\mathrm{CO})\left(\mathrm{PCy}_{3}\right)_{2}(\mathrm{py})$ & yellow & $\begin{array}{c}56.29 \\
(56.39)\end{array}$ & $\begin{array}{c}7.95 \\
(8.11)\end{array}$ & $\begin{array}{c}3.98 \\
(3.96)\end{array}$ & $\begin{array}{c}1.60 \\
(1.57)\end{array}$ & & $"$ \\
\hline $\mathrm{OsDCl}(\mathrm{CO})\left(\mathrm{PCy}_{3}\right)_{2}$ & $\begin{array}{l}\text { Crystals red } \\
\text { Powder yellow }\end{array}$ & $\begin{array}{c}53.87 \\
(54.42)\end{array}$ & $\begin{array}{c}8.28 \\
(8.41)\end{array}$ & $\begin{array}{c}4.50 \\
(4.34)\end{array}$ & & & $"$ \\
\hline $\mathrm{RuHCl}(\mathrm{CO})\left(\mathrm{PCy}_{3}\right)_{2}$ & $\begin{array}{l}\text { Crystals orange } \\
\text { Powder yellow }\end{array}$ & $\begin{array}{l}60.02 \\
(61.16)\end{array}$ & $\begin{array}{l}8.87 \\
(9.30)\end{array}$ & $\begin{array}{l}5.15 \\
(4.88)\end{array}$ & & $\begin{array}{l}2.20 \\
(2.22)\end{array}$ & $"$ \\
\hline $\mathrm{RuHCl}(\mathrm{CO})\left(\mathrm{PCy}_{3}\right)_{2}(\mathrm{py})$ & yellow & $\begin{array}{c}62.63 \\
(62.62)\end{array}$ & $\begin{array}{r}8.90 \\
(9.01)\end{array}$ & $\begin{array}{c}4.40 \\
(4.40)\end{array}$ & $\begin{array}{c}2.06 \\
(1.74)\end{array}$ & & $"$ \\
\hline$\left(\mathrm{PCy}_{3} \mathrm{H}\right)\left(\mathrm{FeCl}_{4}\right)$ & yellow & $\begin{array}{c}44.32 \\
(45.12)\end{array}$ & $\begin{array}{c}6.98 \\
(7.15)\end{array}$ & $\begin{array}{c}29.34 \\
(29.60)\end{array}$ & & & 5.9 \\
\hline & orange & $\begin{array}{c}32.96 \\
(32.91)\end{array}$ & $\begin{array}{c}5.27 \\
(5.22)\end{array}$ & $\begin{array}{c}48.37 \\
(48.66)\end{array}$ & & & 6.2 \\
\hline$\left(\mathrm{PCy}_{3} \mathrm{H}\right)_{2}\left(\mathrm{OsCl}_{6}\right)$ & yellow & $\begin{array}{l}44.89 \\
(44.77)\end{array}$ & $\begin{array}{l}7.23 \\
(7.10)\end{array}$ & $\begin{array}{l}21.48 \\
(22.02)\end{array}$ & & & 3.0 \\
\hline
\end{tabular}

Theoretical values are given in parentheses. 
hydridocarbonyl phosphine complexes of the platinum metals ${ }^{3,4}$. For this complicated redox reaction, which is performed in boiling alcohols, a mechanism is suggested by Chatt et al. ${ }^{5}$ and $V a s k a^{6}$. The initial step is the formation of an alkoxide complex,I, which is followed by hydride transfer to give the aldehyde complex, II, which then breaks down to give alkane and the carbonyl complex III:

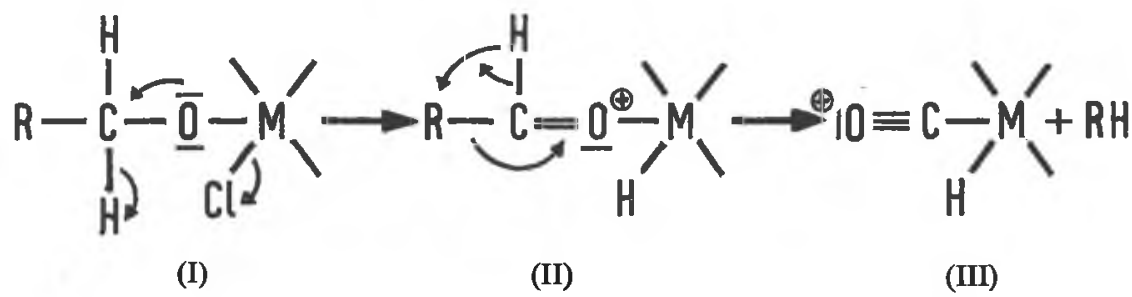

The course of the reaction for the tricyclohexylphosphine complex of osmium(II) may be written as:

$$
\begin{aligned}
& \mathrm{K}_{2} \mathrm{OsCl}_{6}+3 \mathrm{PCy}_{3}+\mathrm{RCH}_{2} \mathrm{OH} \longrightarrow\mathrm{OsHCl(CO})\left(\mathrm{PCy}_{3}\right)_{2}+\mathrm{RH} \\
&+\mathrm{HCl}+\mathrm{PCy}_{3} \mathrm{Cl}_{2}+2 \mathrm{KCl}
\end{aligned}
$$

The crystals of the hydridocarbonyl complexes are stable in air for some hours, but the yellow benzene solutions decompose in air within a few minutes. The compounds are diamagnetic, indicating a low spin $\mathrm{d}^{6}$-configuration. The complexes are only slightly soluble in the usual organic solvents and it was not possible to obtain n.m.r. spectra.

The infrared spectra (nujol mulls) in the $1800-2100 \mathrm{~cm}^{-1}$ range show for these hydridocarbonyl complexes one band attributable to vCO stretching vibration at about $1900 \mathrm{~cm}^{-1}$ and one band at about 2000 $\mathrm{cm}^{-1}$ attributable to $\mathrm{vM}-\mathrm{H}$ (Table II). Recently dicarbonyl compounds of ruthenium with the ligand $\mathrm{PCy}_{3}$ have been reported by $W$. Hieber and $P . J o h n^{7,8}$. In these compounds the vCO stretching vibrations have been observed in the $1960-2030 \mathrm{~cm}^{-1}$ range. The increment of these frequencies of about $100 \mathrm{~cm}^{-1}$ can be attributed to the reduced basicity of the ruthenium caused by the two CO groups. In benzene solution the infrared spectra show a decreased intensity for the $\mathrm{vRu}-\mathrm{H}$ stretching vibration and the vOs-H was not observed. This may be explained

${ }^{3}$ L. Vaska and J. W. Diluzio, J. Amer. Chem. Soc. 83, 1262 (1961).

${ }^{4}$ J. Chatt and B. L. Shaw, Chem. and Ind. 931 (1960).

5 J. Chatt, B. L. Shaw and A. E. Field, J. Chem. Soc. 3466 (1964).

6 L. Vaska, J. Amer. Chem. Soc. 86, 1943 (1964).

7 W. Hieber and P. John, Chem. Ber. 103, 2161 (1970).

${ }^{8}$ P. John, ibid. 103, 2178 (1970). 
by the hypothesis that the benzene molecule can fit into the cavity above the hydrido hydrogen and makes it inactive in the infrared region ${ }^{9}$. In the deuteriated Os-complex prepared from $\mathrm{K}_{2} \mathrm{OsCl}_{6}$, $\mathrm{PCy}_{3}$ and $\mathrm{C}_{2} \mathrm{H}_{5} \mathrm{OD}$, the expected frequency shift for a covalent osmium hydrogen bond was found (vOs-D at $1508 \mathrm{~cm}^{-1}$ ). Another new band was observed in the spectrum of the deuteride at $619 \mathrm{~cm}^{-1}$ and was tentatively assigned to $\delta \mathrm{Os}-\mathrm{D}$. The corresponding region in the spectrum of the hydride was obscured by overlapping with the absorptions of the ligand $\mathrm{PCy}_{3}$.

On standing in air the benzene solution of the ruthenium and osmium hydridocarbonyl complex shows a new band in the infrared spectrum at $1935 \mathrm{~cm}^{-1}$, and the band at about $1900 \mathrm{~cm}^{-1}$ decreases in intensity. A brown precipitate was formed in the solution. This suggests reaction of the complex with $\mathrm{O}_{2}$ or $\mathrm{CO}_{2}$, resulting in a shift of the vCO stretching vibration. A pure compound from this reaction has not yet been obtained. The infrared spectrum (KBr-disc) of the complex $\mathrm{OsHCl}(\mathrm{CO})$ $\left(\mathrm{PCy}_{3}\right)_{2}$ performed in air $^{2}$ gives an additional strong band at $1935 \mathrm{~cm}^{-1}$, suggesting also reaction with $\mathrm{O}_{2}$ or $\mathrm{CO}_{2}$. In the complex $\mathrm{OsHCl}(\mathrm{CO})$ $\left(\mathrm{PPh}_{3}\right)_{3}$ an additional band was also observed at $1930 \mathrm{~cm}^{-1}$ with the Beckman IR-4 instrument, but no explanation has been given ${ }^{6}$.

The infrared spectrum in the $700-200 \mathrm{~cm}^{-1}$ range shows for the ruthenium complex a $v \mathrm{Ru}-\mathrm{Cl}$ stretching vibration at $337 \mathrm{~cm}^{-1}$ and a $\delta \mathrm{CO}$ at $588 \mathrm{~cm}^{-1}$; for the osmium complex a vOs- $-\mathrm{Cl}$ at $302 \mathrm{~cm}^{-1}$ and the $8 \mathrm{CO}$ at $607 \mathrm{~cm}^{-1}$.

In the mass spectrum of the osmium complex $\left(180^{\circ}\right)$ the parent molecule ion is observed in high abundance. The relative abundances of the peaks in this cluster agree with the calculated ratios. Other fragment ions having $m / e$ higher than $280\left(\mathrm{PCy}_{3}\right)$ were observed in very low intensity (the relative intensity in comparison with the parent ion is lower than 0.05). Unfortunately the ruthenium complex is far less volatile, so that recording its mass spectrum $\left(220^{\circ}\right)$ is difficult. Molecular ions are present in low abundance, however the composition cannot, as in the case of the osmium analogue, be confirmed by the isotopic ratios; this is probably due to the partial loss of a hydrogen atom from the molecular ions.

The pyridine adducts were easily obtained by addition of pyridine to the hydridocarbonyl complexes. The assignments of the important infrared bands are given in Table II. We found for these adducts a decrease of the $\mathrm{vCO}$ stretching frequencies in comparison with the hydridocarbonyl complexes. This may be explained assuming the

9 J. Chatt and R. G. Hayter, J. Chem. Soc. 2605 (1961). 
ligand pyridine to be a strong $\sigma$-donor and a weak $\pi$-back acceptor. This results in an increase in the basicity of the metal ${ }^{10}$.

Table II

The major infrared absorption bands $\left(\mathrm{cm}^{-1}\right)$ in the range $4000-200 \mathrm{~cm}^{-1}$

\begin{tabular}{|c|c|c|c|c|c|c|}
\hline Compounds & $\begin{array}{c}\text { vCO } \\
\text { (nujol) }\end{array}$ & $\begin{array}{c}\text { vCO } \\
\text { (benzene) }\end{array}$ & $\begin{array}{c}\mathrm{vM}-\mathrm{H} \\
\text { or } \\
\mathrm{vM}-\mathrm{D} \\
(\text { nujol) }\end{array}$ & $\begin{array}{l}v P-H \\
\text { (nujol) }\end{array}$ & $\begin{array}{c}v \mathbf{M}-\mathbf{X} \\
\text { (nujol) }\end{array}$ & $\begin{array}{c}\delta \mathrm{CO} \\
\text { (nujol) }\end{array}$ \\
\hline OsHCl(CO) (PCy & $1887(\mathrm{~s})$ & 1884(s) & 2012(w) & & 303(s) & $607(s)$ \\
\hline $\mathrm{OsDCl}(\mathrm{CO})\left(\mathrm{PCy}_{3}\right)_{2}$ & $1885(\mathrm{~s})$ & $1884(\mathrm{~s})$ & $1508(\mathrm{w})$ & & 303(s) & 607(s) \\
\hline $\mathrm{OsHCl}(\mathrm{CO})\left(\mathrm{PCy}_{3}\right)_{2}(\mathrm{py})$ & $1860(s)$ & & $2040(w)$ & & (a) & $618(s)$ \\
\hline OsDCl(CO) $\left(\mathrm{PCy}_{3}\right)_{2}(\mathrm{py})$ & $1861(s)$ & & $1520(w)$ & & (a) & $618(\mathrm{~s})$ \\
\hline $\operatorname{RuHCl}(\mathrm{CO})\left(\mathrm{PCy}_{3}\right)_{2}$ & $1905(\mathrm{~s})$ & $1902(\mathrm{~s})$ & $2030(w)$ & & $337(s)$ & 588(s) \\
\hline $\mathrm{RuHCl}(\mathrm{CO})\left(\mathrm{PCy}_{3}\right)_{2}(\mathrm{py})$ & $1881(\mathrm{~s})$ & & 2038(w) & 0 & & 604(s) \\
\hline$\left(\mathrm{PCy}_{3} \mathrm{H}\right)\left(\mathrm{FeCl}_{4}\right)$ & & & & $\begin{array}{c}2405(w) \\
b\end{array}$ & 382(s) & \\
\hline$\left(\mathrm{PCy}_{3} \mathrm{H}\right)\left(\mathrm{FeBr}_{4}\right)$ & & & & 2395(vw) & 293(s) & \\
\hline$\left(\mathrm{PCy}_{3} \mathrm{H}\right)_{2}\left(\mathrm{OsCl}_{6}\right)$ & & & & $2380(w)$ & $305(s)$ & \\
\hline
\end{tabular}

(a) For the pyridine adducts a definite assignment of $v \mathrm{M}-\mathrm{Cl}$ is not possible mainly because of overlapping with $\mathbf{M}-\mathbf{N}$ stretching vibrations.

Interesting data have been found for the mass spectrum of the deuteriated Os-complex (Fig. 1). The left side shows the mass spectrum of the osmium compound and the right side that of the deuteriated analogue in the 280 region. The cluster $\mathrm{PCy}_{3}$ has the most intense peak at 280. Comparison of the osmium complex and its deuteriated derivative shows for the latter the presence of peaks higher than 280, in the 280-291 range. This indicates a hydrogen deuterium exchange of the ligand for the deuteriated Os-complex during the preparation of this complex. As indicated by the mass spectrum, deuteriation of $\mathrm{PCy}_{3}$ was not observed in the reaction of $\mathrm{PCy}_{3}$ and boiling deuteriated ethanol during 72 hours.

We were able to isolate the free ligand $\mathrm{PCy}_{3}$ from the deuteriated Os-compound by heating the complex in a vacuum at $250^{\circ}$. The mass spectrum also shows mass peaks in the 280-291 range. The mixture of ruthenium products obtained from hydrated $\mathrm{RuCl}_{3}, \mathrm{PCy}_{3}$ and $\mathrm{C}_{2} \mathrm{H}_{5} \mathrm{OD}$

10 D. F. Shriver, Acc. Chem. Res. 73 (1966). 
also shows deuteriation of $\mathrm{PCy}_{3}$ as indicated by the mass spectrum showing the presence of peaks at $m / e$ 280-291, analogous with the osmium complex. Hydrogen deuterium exchange has also been found by Parshall, Schunn and Knoth ${ }^{1-13}$ in hydrido complexes with aromatic substituted phosphine ligands. Recently, hydrogen deuterium exchange has also been observed in alkanes ${ }^{14}$. Hydrogen deuterium exchange of the ligand was also studied on deuteriation of the complexes with deuterium gas. The complexes were allowed to equilibrate with deuterium gas in benzene at room temperature for 28 days. The gas was analysed by mass spectrometry and the number of exchanged hydrogen atoms was calculated from the fraction of hydrogen atoms in the gas phase of the system (Table III). Under these conditions the number of hydrogen atoms exchanged for deuterium was for the osmium complex

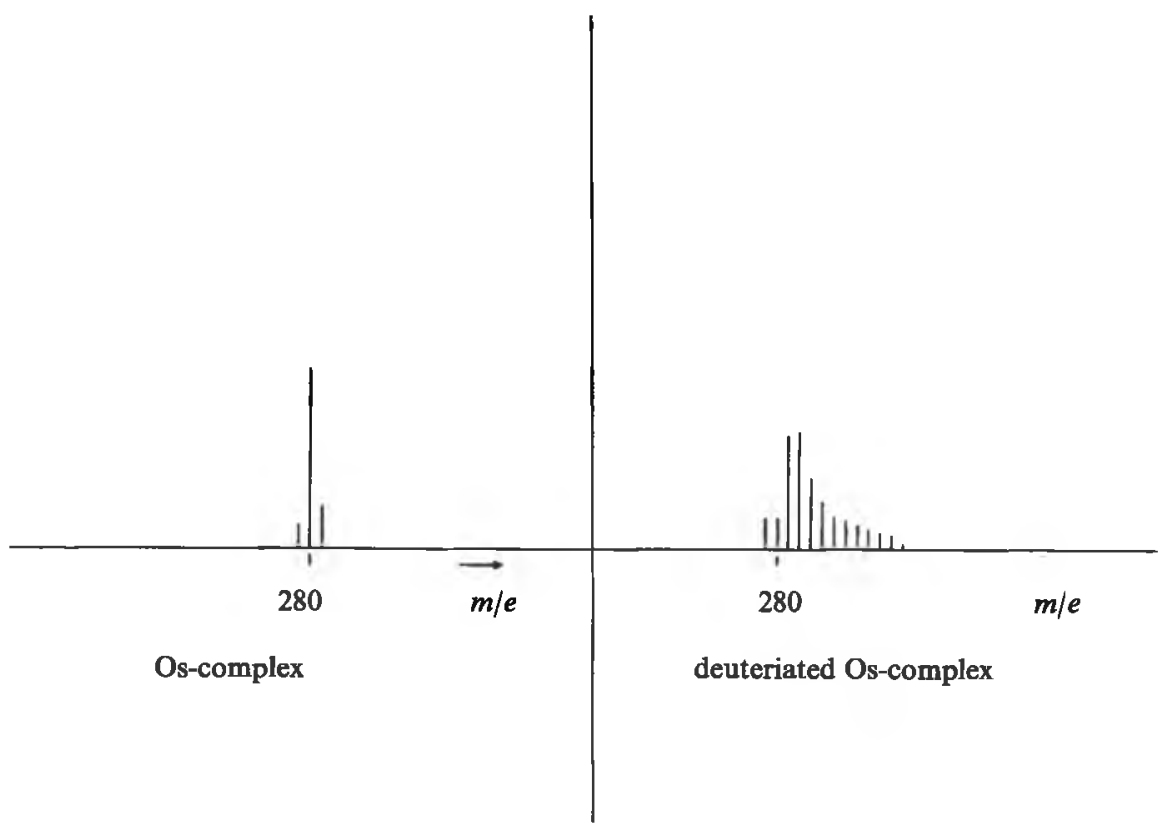

Fig. 1. Mass spectra in the 280 region.

11 G. W. Parshall, J. Amer. Chem. Soc. 90, 1669 (1968).

12 W. H. Knoth and R. A. Schunn, ibid. 91, 2400 (1969).

${ }^{13}$ G. W. Parshall, W. H. Knoth and R. A. Schunn, ibid. 91, 4990 (1969).

14 R. J. Hodges, D. E. Webster and P. B. Wells, Chem. Comm. 9, 462 (1971). 
2.4 and for the ruthenium complex 3.5. After evaporating the benzene solution of these complexes the mass spectrum of the osmium complex shows mass peaks in the 280-286 range and for the ruthenium complex in the 280-291 range, indicating deuteriation of $\mathrm{PCy}_{3}$. These results indicate that only some of the hydrogen atoms can take part in the exchange reaction with deuterium. In the mass spectra we observe that the number of detectable hydrogen atoms exchanged with deuterium in $\mathrm{PCy}_{3}$ is maximal 11.

Table III

Exchange reactions of the complexes with $\mathrm{D}_{\mathbf{2}}$.

\begin{tabular}{|c|c|c|c|c|c|c|}
\hline mmole Complex & $\underset{\text { (mmole) }}{\mathbf{D}_{2}}$ & \multicolumn{3}{|c|}{ Gascomposition \% } & $\begin{array}{c}\text { Reaction- } \\
\text { time } \\
\text { (days) }\end{array}$ & $\begin{array}{c}\text { no. of } \\
\text { exchange } \\
\text { dH-at }\end{array}$ \\
\hline $0.138 \mathrm{RuHCl}(\mathrm{CO})\left(\mathrm{PCy}_{3}\right)_{2}$ & 4.6 & 89.8 & 9.8 & 0.3 & 28 & 3.5 \\
\hline $0.123 \mathrm{OsHCl}(\mathrm{CO})\left(\mathrm{PCy}_{3}\right)_{2}$ & 4.9 & 94.2 & 5.7 & 0.2 & 28 & 2.4 \\
\hline
\end{tabular}

The hydrogen-deuterium exchange may be explained by a rapid equilibrium involving formation of a metal-carbon bond and splitting off of hydrogen (Scheme I).

Scheme I

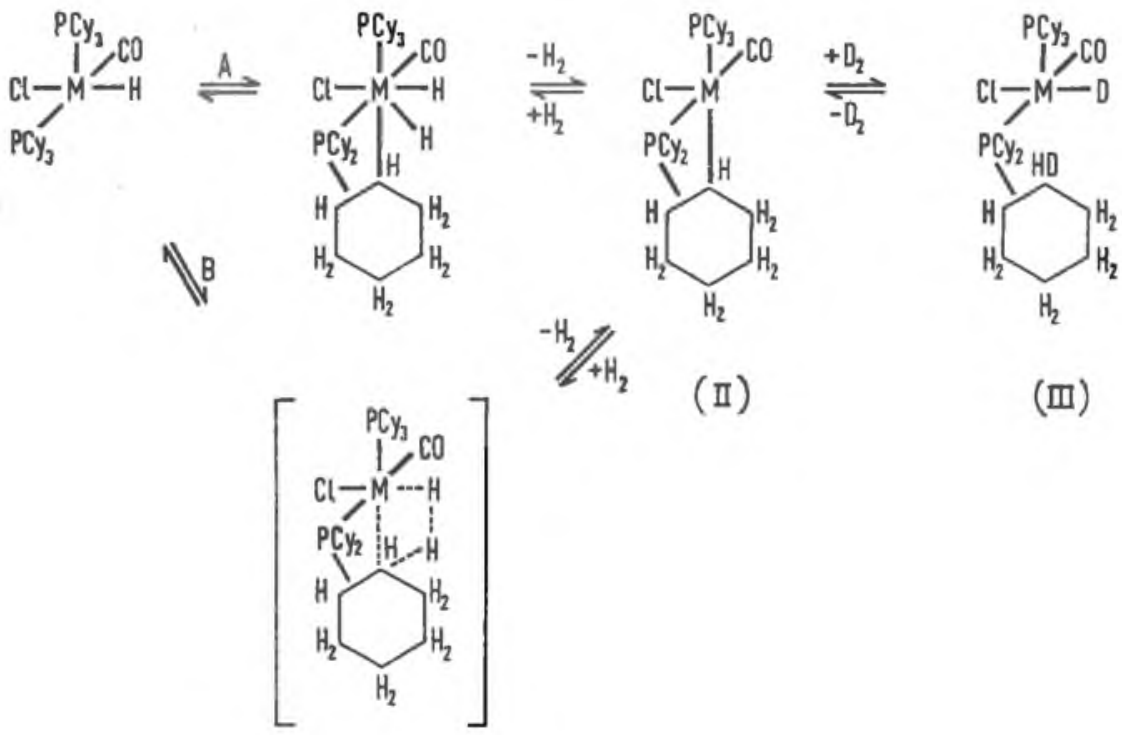


This may occur by insertion of the metal complex into $\mathrm{C}-\mathrm{H}$ bonds (route A) or via a transition state in which formation of metal-carbon bond and splitting off of hydrogen is concerted (route $\mathrm{B}$ ). A metal-carbon bond was also found in the platinum complex $\mathrm{PtCl}\left(-\mathrm{CH}_{2} \mathrm{CH}_{2} \mathrm{CH}_{2}-\mathrm{PBu}\right)$ $\left(\mathrm{PBu}_{2}^{t} \mathrm{Pr}^{\underline{n}}\right)^{15}$. The interaction of $\mathrm{MCl}(\mathrm{CO}) \mathrm{PCy}_{3}\left(\mathrm{PCy}_{2} \mathrm{C}_{6} \mathrm{H}_{10}\right)$ (compound II) with $\mathrm{D}_{2}$ gives $\mathrm{MCl}(\mathrm{CO}) \mathrm{D}\left(\mathrm{PCy}_{3}\right)\left(\mathrm{PCy}_{2} \mathrm{C}_{6} \mathrm{H}_{10} \mathrm{D}\right)$ (compound III) or in a similar way more highly deuteriated compounds. For a complete exchange of the $\alpha$-hydrogen atoms, as observed in the complex $\mathrm{CoHN}_{2}\left(\mathrm{PPh}_{3}\right)_{3}{ }^{11}$, we expect that 24 hydrogen atoms exchange with deuterium. The average number is only $2-4$. In the complex $\mathrm{RhH}\left(\mathrm{PPh}_{3}\right)_{4}$ the number of hydrogen atoms exchanged with deuterium was also reported to be only $7-9^{16}$. A complete exchange may be hindered by steric effects.

The hydrogen-deuterium exchange in the complexes prepared with deuteriated ethanol may be catalysed by the presence of $\mathrm{DCl}$ which is formed during the reaction. Further investigation of this reaction and the determination of the deuteration site are in progress.

\section{(b) Phosphonium compounds}

Hydridocarbonyl complexes of iron could not be obtained by reaction of iron halides with $\mathrm{PCy}_{3}$ in alcohols. We obtained yellow products, in low yield, of the formula $\mathrm{FeX}_{4} \mathrm{PHCy}_{3}$ which showed no bands in the $2000 \mathrm{~cm}^{-1}$ region. The yield was greatly increased on working in acid medium. Magnetic susceptibility measurements show for the chlorine product a magnetic moment of 5.9 B.M. and for the bromine compound 6.2 B.M. The infrared spectra show a $\mathrm{vP}-\mathrm{H}$ stretching vibration at about $2400 \mathrm{~cm}^{-1}$; the $v \mathrm{Fe}-\mathrm{Cl}$ stretching vibration is found at $382 \mathrm{~cm}^{-1}$ and the $v \mathrm{Fe}-\mathrm{Br}$ at $293 \mathrm{~cm}^{-1}$, which is in agreement with $\mathrm{FeX}_{4}$ ions ${ }^{17}$. The compound $\left(\mathrm{PCy}_{3} \mathrm{H}\right)_{2}\left(\mathrm{OsCl}_{6}\right)$ has a magnetic moment of 3.04 B.M., which is in agreement with a $\mathrm{d}^{4}$ configuration in a strong octahedral field. The $v \mathrm{P}-\mathrm{H}$ was observed at $2380 \mathrm{~cm}^{-1}$ and the $v \mathrm{Os}-\mathrm{Cl}$ at 305 $\mathrm{cm}^{-1}$.

Conductance measurements showed $\left(\mathrm{PCy}_{3} \mathrm{H}\right)\left(\mathrm{FeBr}_{4}\right)$ to be a $1: 1$ electrolyte in nitrobenzene in the concentration range $0.5-3 \mathrm{mmole} / 1$ $\left(\Lambda_{\mathrm{o}} 28.3 \mathrm{ohm}^{-1} \mathrm{~cm}^{2} \mathrm{~mole}^{-1}\right)$ and $\left(\mathrm{PCy}_{3} \mathrm{H}\right)_{2}\left(\mathrm{OsCl}_{6}\right)$ a $1: 2$ electrolyte in nitrobenzene in the concentration range $0.1-1.2 \mathrm{mmole} / 1\left(\Lambda_{0} 60.1\right.$ $\mathrm{ohm}^{-1} \mathrm{~cm}^{2}$ mole $^{-1}$ ).

15 A. J. Chenney, B. E. Mann, B. L. Shaw and R. M. Slade, Chem. Comm. 1177 (1970).

16 Takashi Ito, Shoji Kitazume, Akio Yamamoto and Sakuji Ikeda, J. Amer. Chem. Soc. 92, 3011 (1970).

17 R. J. H. Clark, Spectrochim. Acta 21, 955 (1965). 
The combined experimental data indicate that these complexes can be formulated thus as $\left(\mathrm{PCy}_{3} \mathrm{H}\right)^{+}\left(\mathrm{FeX}_{4}\right)^{-}$and $\left(\mathrm{PCy}_{3} \mathrm{H}\right)_{2}^{+}\left(\mathrm{OsCl}_{6}\right)^{2-}$.

\section{Experimental section}

\section{Preparation of tricyclohexylphosphine}

The ligand was prepared as described by Issleib et al..$^{18}$ and was purified by recrystallisation from ethyl alcohol (m.p. $78^{\circ}$ ).

Osmium and ruthenium salts $\mathrm{K}_{2} \mathrm{OsCl}_{6}$ and $\left(\mathrm{NH}_{4}\right)_{2}\left(\mathrm{OsCl}_{6}\right)$ were prepared by the methods described in the literature ${ }^{19}$. Hydrated $\mathrm{RuCl}_{3}$ was commercial by available (Fa. Drijfhout, Amsterdam).

Preparation of the hydridocarbonyl complexes $\mathrm{MHCl}(\mathrm{CO})\left(\mathrm{PCy}_{3}\right)_{2}$ with $\mathrm{M}=\mathrm{Ru}$ or Os.

1 mmole of $\mathrm{K}_{2} \mathrm{OsCl}_{6}$ was added to a solution of 3 mmoles of $\mathrm{PCy}_{3}$ in 2-methoxyethanol under a nitrogen atmosphere. The mixture was heated for 48 hours at $130^{\circ}$. After cooling to room temperature the red cystals were filtered, washed with ethanol and dried in a high vacuum.

The yellow crystals of the ruthenium complex were obtained using a solution of hydrated $\mathrm{RuCl}_{3}$ in 2-methoxyethanol instead of $\mathrm{K}_{2} \mathrm{OsCl}_{6}$.

The deuteriated Os-compound was prepared on a similar way by reaction of $\mathrm{K}_{2} \mathrm{OsCl}_{6}$, $\mathrm{PCy}_{3}$ and $\mathrm{C}_{2} \mathrm{H}_{5} \mathrm{OD}$ during 72 hours. A pure deuteriated ruthenium compound could not be isolated.

Preparation of the pyridine complexes $\mathrm{MHCl}(\mathrm{CO})\left(P C y_{3}\right)_{2}(p y)$ with $M=R u$ or Os

The pyridine adduct was prepared by addition of an excess of pyridine with stirring to the hydridocarbonyl complex. The mixture was stirred for 12 hours at room temperature. The yellow precipitate was filtered, washed with ethanol and dried in a high vacuum.

\section{Preparation of the phosphonium compounds}

(a) $\left(\mathrm{PCy}_{3} \mathrm{H}\right)_{2}\left(\mathrm{OsCl}_{6}\right)$.

(a) 1 mmole of $\left(\mathrm{NH}_{4}\right)_{2} \mathrm{OsCl}_{6}$ was added to a solution of 3 mmoles of $\mathrm{PCy}_{3}$ in ethanol. The mixture was heated for 72 hours at $80^{\circ}$. After cooling to room temperature the precipitate was filtered and water was added to the filtrate. The resulting yellow precipitate from the filtrate was filtered, washed with water and ethanol and dried in a vacuum over $\mathrm{P}_{2} \mathrm{O}_{5}$.

(b) $\left(\mathrm{PCy}_{3} \mathrm{H}\right)\left(\mathrm{FeX}_{4}\right)$ with $\mathrm{X}=\mathrm{Cl}$ or $\mathrm{Br}$.

A solution of 1 mmole of hydrated $\mathrm{FeX}_{3}$ in $2 N-\mathrm{HX}$ was added with stirring to a solution of 1 mmole of $\mathrm{PCy}_{3}$ in ethanol. The yellow precipitate was filtered, washed with ethanol and dried in a vacuum over $\mathbf{P}_{2} \mathrm{O}_{5}$.

18 K. Issleib and A. Brack, Z. Anorg. Allg. Chemie 227, 258 (1954).

19 F. P. Dwyer and J. W. Hogarth, J. Roy. Soc. N.S. Wales 84, 194 (1951). 
Exchange reaction of the hydrido complex with $\mathrm{D}_{2}$

A flask containing a deoxygenated benzene solution of the complex and a microstirring bar was connected to a vacuum line and a manometer. The flask was cooled in liquid nitrogen, evacuated and then filled with deuterium. The reaction was continued at room temperature with vigorous stirring; the contents of the flask were frozen by liquid nitrogen. A noncondensable gas at $-196^{\circ}$ in the system was submitted to mass spectral analysis. The results are given in Table III.

\section{Physical measurements}

Magnetic susceptibilities were measured on a Gouy balance. The balance was calibrated with $\mathrm{HgCo}(\mathrm{NCS})_{4}$. The infrared spectra were obtained with a Perkin Elmer 257 spectrophotometer for the $4000-700 \mathrm{~cm}^{-1}$ range and a Hitachi EPI-L for the $700-200 \mathrm{~cm}^{-1}$ region. The spectra were taken using the nujol mull technique or in benzene solution. The preparations of the benzene solution and the nujol mulls of the hydridocarbonyl complexes were performed in a Vac train HE 193-1 glove box under a nitrogen atmosphere.

The mass spectra of the hydridocarbonyl complexes were recorded on a Varian-Atias SM-1B double focussing instrument under low resolution conditions. The samples were introduced into the mass spectrometer by a direct insertion system. Mass spectra of the gases were obtained using a Varian CH 5 mass spectrometer.

Electrical conductivities were measured with a Methrohm kunduktoscoop E 365 and a Philips PR 9510/00 conductivity cell at $25^{\circ}$.

\section{Acknowledgement}

Thanks are due to Prof. Dr. Ir. J. J. Steggerda for discussions and for reading this manuscript and to Drs. F. Gerhartl and Mr. L. Hendriks for recording the mass spectra. 